MIOMIR KORAĆ

001.92:902(497.11)

Institute of Archaeology,

338.485:904"652"(497.11)

Belgrade, Serbia

711.52:902(497.11)

misko@turing.mi.sanu.ac.rs

COBISS.SR-ID 228050444

EMILIJA NIKOLIĆ

Original research article

Institute of Archaeology,

Received: May $24^{\text {th }} 2016$

Belgrade, Serbia

Accepted: June $20^{\text {th }} 2016$

MILICA TAPAVIČKI-ILIĆ

Institute of Archaeology,

Belgrade, Serbia

\title{
ARCHAEOLOGICAL PARK OF VIMINACIUM: BEAUTIFYING A COMMUNITY WITH CULTURAL HERITAGE
}

\begin{abstract}
It seems that besides huge ecological problems and the disappearance of arable land as a result of the spread of the mining industry in the area of Kostolac, the local community, with its relationship towards the environment and heritage, is the greatest barrier to the cultural and touristic development of the area.

Can we use the verb "to beautify" for any positive change within the community? The Viminacium management team has taken the lead in trying to make many changes that will bring that beauty.
\end{abstract}

KEYWORDS: VIMINACIUM, LOCAL COMMUNITY, CULTURAL HERITAGE, PLACE, IDENTITY, COMMITMENT, DEPENDENCE, KNOWLEDGE, TO BEAUTIFY, TO NEGLECT, TOURISM.

\section{INTRODUCTION ${ }^{1}$}

Although in 1949, the excavated sites of Viminacium, near the modern town of Kostolac, were protected by law (Rešenje 1949) and in 1979, $V i$ minacium was determined as an immovable cultural property of exceptional importance, (Odluka 1979), illegal excavations in search of valuable goods that could be sold abroad and the distribution of all the ancient building material that could be obtained were the every day activities of local people until the beginning of this century and the

1 The article results from the project: Viminacium, Roman city and military camp - research of material and non- material culture of inhabitants by using the modern technologies of remote detection, geophysics, GIS, digitalization and $3 D$ visualization (no 47018), funded by The Ministry of Education, Science and Technological Development of the Republic of Serbia. introduction of physical protection at this archaeological site.

However, it was not only the physical protection that saved the site. Another, maybe even more important factor, were the people moving around the site every single day. Archaeologists were excavating and presenting their work, the visitors came and the area came to life. The result of this was that illegal excavations stopped and tourism started to develop. The Viminacium Archaeological Park was opened for visitors in 2006. In 2009, it was established as an official archaeological site with its boundaries and system of use and protection. (Одлука 2009)

Many young people from the surrounding area are now employed in Viminacium, with their monthly income dependant on the profit Park gen- 
erates from tourists. The souvenirs on sale include items that they make. In the process of developing the infrastructure and building facilities, the participation of local companies is fostered. Members of the local community, a great majority of who are Roma people, participate in the archaeological excavations as labourers. They also work as Park staff in the service and maintenance sector. They no longer view Viminacium as a place for illegal excavations, but as a valuable piece of their own cultural heritage (Fig. 1).

The beginning of foreign tourist interest in the area is visible thanks to the promotion of the Viminacium Archaeological Park and the engagement of its management team. (Одлука 2012, 36) In 2006, on the bank of the Danube in Kostolac, a port for large passenger ships, carrying tourists from all around the world, was established. Along with presenting Viminacium, a modern supply infrastructure, along with complete signalization along important roads in the area were completed (Fig. 2). National exhibitions and opera, international conferences and meetings, concerts and movie making have now become common events in Viminacium (Fig. 3).

A variety of different cultures have been existed in the Kostolac region since the $8^{\text {th }}$ millennium. One of the most famous is the Eneolithic "Kostolac culture", but also the Bronze Age culture that included the world famous figurine of the "Idol of Kličevac". (Спасић-Ђурић 2009, 15-17) In the $1^{\text {st }}$ century $A D$, Viminacium, the capital of the Roman province of Moesia Superior was founded. The city and the important legionary fortress flourished during the following centuries, along the way suffering from destructions and conquests, and finally fell to the Slav attacks of the $7^{\text {th }}$ century. (Mirkovic $1968,63-73$ ) On the hill above today's village, one of the most important Serbian lands of the Middle Ages was settled. (Шпехар 2007, 363) The miners in the village, considered as the instigators of the industrial age in Serbia, in 1870, formed the first mining colony there and, after the Second World War, their descendants founded the urban settlement of Kostolac. Underground mining stopped with the establishment of the first open pit coal mine (Вучетић 2010, 2, 14-18, 30), the basin of which today covers a huge exploitation area. The mine's power plants are responsible for a significant part of the entire electrical energy production in Serbia today. (Годишњи извештај 2014, 26-27) A large part of the rural area, which was once arable, with fields, vineyards and woods, (Mašinski fakultet $2010,44)$ has disappeared due to the advancing surface mine, which occupies a lot of land and has destroyed the habitat of many species. (Локални план 2009, 39) The area today comprises the open pit with heavy machinery, partly re-cultivated land, the thermo power plant complex with coal deposits and infrastructure objects spread all over the fields, (Mašinski fakultet 2010, 44) but also the presented site of Viminacium with its contemporary tourist facilities.

With the exhaustion of the coal deposits, the lack of specialisation in agricultural production and with little arable land, in several decades, the problem of employment of the local inhabitants will emerge. After the closing of the old underground mine in the village of Kostolac, "the spirit of the colony... stepped back and floats over the area that we left to... whom?" (Вучетић 2010, 54) Or, as Felix Kanitz once wrote of the local people who used to ruin Viminacium; "will these people who inherited the ancient ground be able to build similar, artistically and technically beautified communities?" (Каниц 1989, 542) Is the verb to beautify connected only to the aesthetic or technical development, or can it be used for positive change of any kind within a community? If it can be, are the preservation and promotion of a rich cultural heritage those kind of changes and, consequently, a possible way to sustain the area and keep it alive? 

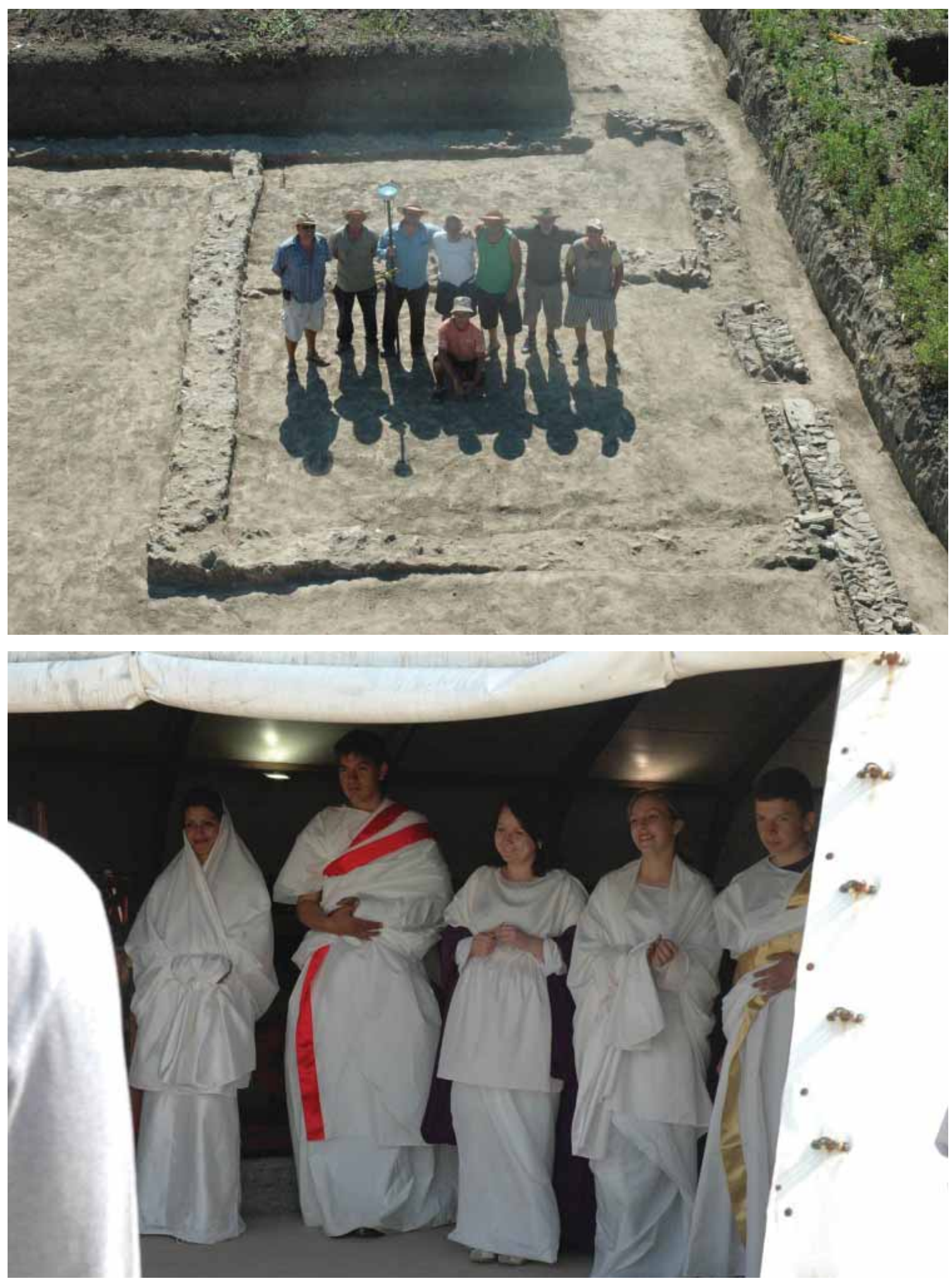

Fig.1 Members of the local community working in the archaeological sites and park of Viminacium. (From the photo documentation of Institute of Archaeology, project Viminacium) 

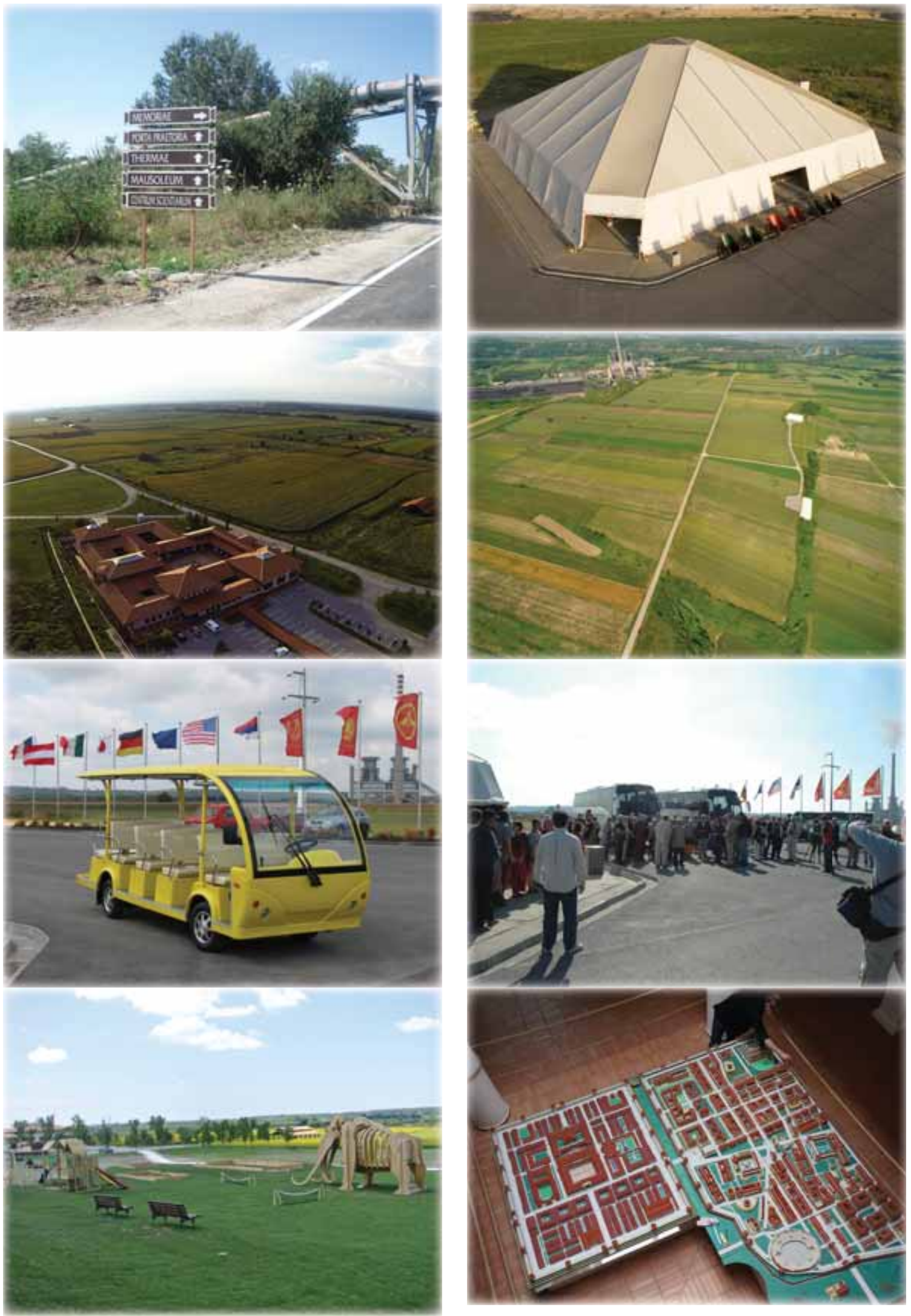

Fig.2 Archaeological park of Viminacium.

(From the photo documentation of Institute of Archaeology, project Viminacium) 


\section{LOCAL COMMUNITY}

The area of the City of Požarevac is among the most economically developed areas of Serbia. (РАПП 2009, 35) Unfortunately, a negative population growth and an unfavourable age structure of the people of the area, indicate a problem, which is one of the most important limitations in the socio-economical development of the whole area around the Viminacium Archaeological Park. (РАПП 2009, 25) The number of inhabitants in the whole region has been decreasing since 1991. (Одлука 2012, 13) The cause of this fact is the permanent migration of people within Serbia, and emigration, mostly from rural areas. (Одлука 2012, 62, 83) Census data shows that the rural population is in the deepest stages of demographic ageing. (Одлука 2012, 23)

Rural inhabitants of the area live in poor conditions, which are actually not always the result of poverty. Most of them live in modest houses, but also own the big luxury ones next to them, with shops and cafes in the basement areas. The big houses are rarely opened, mostly for family gatherings, or when family members temporarily working abroad come home for a vacation. (M.V. 2012, 11) Although some authors justify these acts of investing in the building of houses as the only way to save the earned capital from the work abroad, which was possible during the socialist period after the Second World War, when it was impossible to develop private enterprises and rationally invest the money, (Milosavljević 2010, 4749) there are some records of the same behaviour even before this period. In 1928, the Serbian Ministry of Health determined that these people lived in shacks with no windows, and that there were a lot of rich people with houses and big estates that still slept on a straw floor because, as they put it, "they have learned so, and their ancestors lived like that, lacking nothing." (Milosavljević 2010, 47-49) Fortunately, the situation has slowly started to change during recent years. Many local people do not invest money in houses as before. They buy apartments for their children in Belgrade or other cities in Serbia where they intend them to be educated. Some buy properties abroad or build houses there. However, the wish for grandiosity has survived in all times. One local from the village in Požarevac area spent one million francs building a house in Switzerland. (M.V. 2012, 11)

In the Kostolac area, only $3.1 \%$ of the population is engaged with agriculture, while $48.4 \%$ is connected with the industrial activities of the mine. (Републички завод за статистику 2014, 174-175) That is the reason why the income per inhabitant in Kostolac is much above the national average, (РАПП 2009, 35), even though $41 \%$ of inhabitants of age fifteen and older in the area of Kostolac finished only primary school or are not educated at all. (Републички завод за статистику 2013, 82) According to the results of the census, the population here is ethnically diverse, but Serbs prevail with around $72 \%$, while other ethnic groups are smaller, with the largest one being the Roma people, comprising around $19.50 \%$ of the population. (Републички завод за статистику 2012, 70-71)

\section{NEGLECT OF HERITAGE BY THE COMMUNITY}

The use of historic building material for contemporary purposes, throughout history, has existed in all cultures. (Rodwell 2007, 190) "Byzantine and Bulgarian fortresses, Serbian castles and churches" were built with building material originated from the Viminacium ruins. (Каниц 1989, 150-152, 165, 177-181) In a large number of houses in the nearby villages, one can see Roman bricks used as pavement for auxiliary agricultural facilities. The Austro-Hungarian travel writer and ethnologist, Felix Kanitz, noted in the $19^{\text {th }}$ century that the ruins of luxurious Viminacium were used as "ordinary quarry" (Каниц 1989, 542), saying that all over the place huge amounts of unearthed building material were laying around 
waiting to be removed and that the biggest square shaped bricks, called "Kostolac bricks", intended for yard paving, used to be sold in Požarevac. (Каниц 1989, 179) He also found a richly decorated Roman sarcophagus residing in a village yard with some pigs. (Каниц 1989,181$)$ A $19^{\text {th }}$ century researcher of Viminacium, Mihailo Valtrović, a short time later, noted that local people were dragging around the remains of this Roman town, with two thousand carts full of bricks taken away, decorative stones broken down to be easier lifted, and two hundred graves opened and robbed. (Валтровић 1884a, 3)

It is important to respect the traditions of local communities and to understand its rituals, stories, behaviours and knowledge of the living environment (Mitchell, Buggey 2000, 44-45), so that it can be involved in the management of the place. (Jain 2008, 16) The whole region of Eastern Serbia is rich in various legends, among which are those regarding buried treasures, which almost all the locals search for during their lives, hoping it will bring them instant wealth. (Milosavljević $2010,44)$ In Viminacium, there has been a story, told for a century, about "The Blue Tomb". It was closed and reburied after the archaeologist Miloje Vasić excavated it, and has never been found since. The story is about beautiful paintings in the tomb, depicting grapes and birds of blue colour. (Mikić 2003) This story can be the reason why today the underground hall in the Viminacium exhibition hall, whose ceiling and walls are decorated in blue mosaics, is referred to by some local people as "The Blue Tomb". The legend of a missing Roman "golden chariot" that passed through Viminacium as a gift from a Roman emperor to an Egyptian princess, is present in almost all villages of the region. (Lukić 2009)

Over time, these legends, together with accounts of the removal of ancient building material all over the area, and the trade of movable cultural property in and out of Serbia, actually criminal acts, emerged. Over time, accidental discoveries of treasure turned into targets for the search for archaeological remains. (Milosavljević 2010, 1516) Official, but irregular archaeological excavations of Viminacium during the 20th century, with no protection of the sites, helped this situation develop. Until the excavations, local people thought that the only valuable goods were the gold ones. Archaeological results showed them the real value of other artefacts. (Milosavljević 2010, 15-16) The fact that this region of Serbia is very well connected to other parts of Europe, the invention of metal detectors in the 1970s, war in the 1990s in the region and widespread smuggling in Serbia, made illegal archaeological excavations in the area and the transfer of cultural property over the border larger and easier. This was especially happening in this part of Eastern Serbia, because a great number of the local inhabitants, after the fast industrialisation, the development of the mining and power sector in Serbia, the opening of many workplaces, and the consequent deagrarisation, were engaged in temporary work abroad for years. (Milosavljević 2010, 77) The good financial status of these locals, who have not been engaged in agriculture alone for decades, allowed them to hire labour for land cultivation, leaving them plenty of free time to try to make their "dreams of getting rich quickly" come true. (Milosavljević 2010, 77) During the 1990s, the police repeatedly detained residents of the nearby villages of Požarevac and the leaders of local communities. (Tasić, Dukić, 2005a) All of them owned ancient artefacts, but also a catalogues of finds, metal detectors, and purpose made special ploughs, that were able to plough to a depth of 80cm. (Milosavljević 2010, 34)

Today, the local communities live on land that was once inhabited by other people who are not their ancestors. These traces are still their history that they need to learn about, with pride and understanding, always having in mind that there are other people in this world who also have the right to know the same. (Parker Pearson, Ramilisonina 2004, 236-237) However, from the stories of peasants, one can conclude they are identified with the history of Middle Ages, but the period 

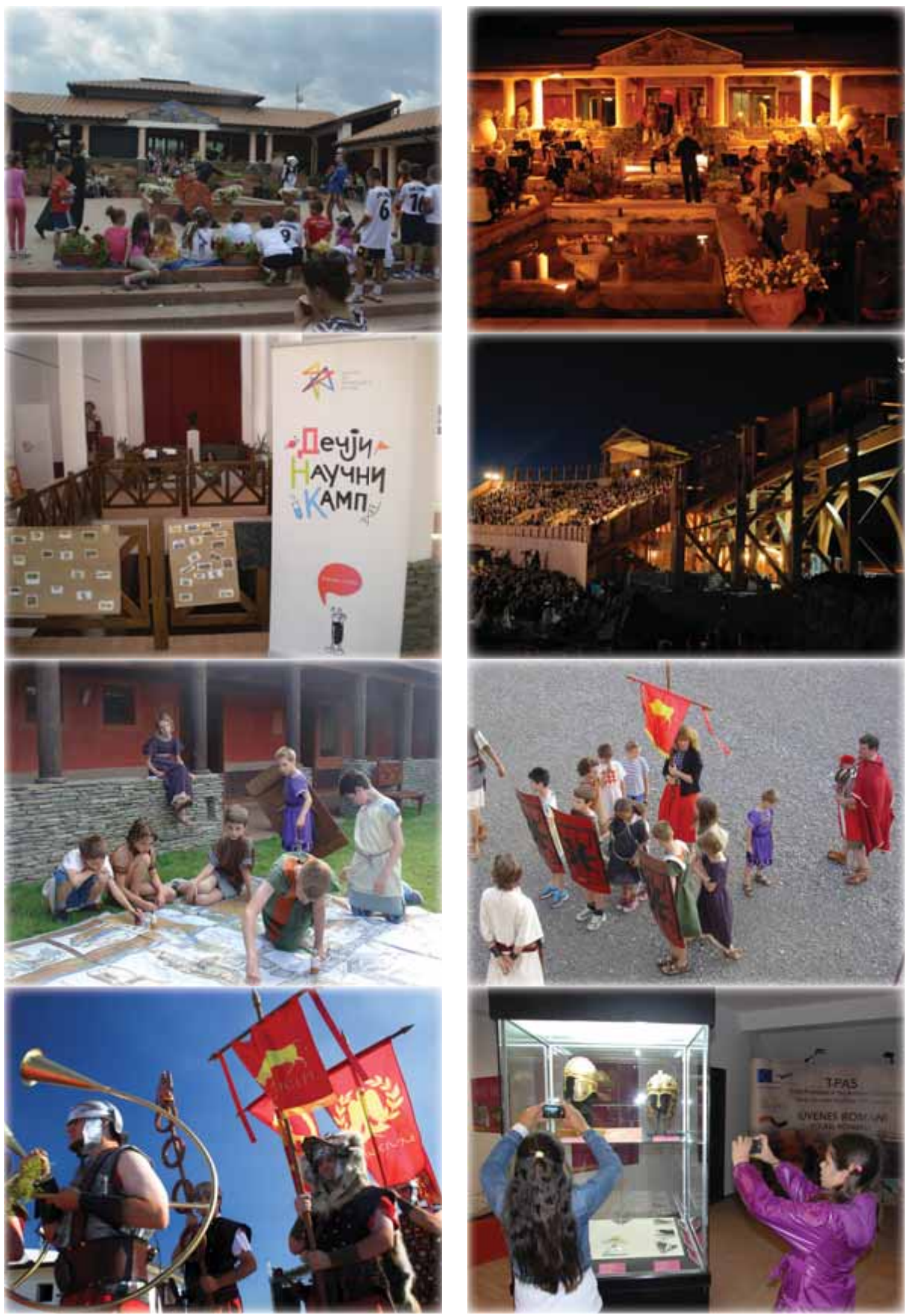

Fig.3 Manifestations in Archaeological park of Viminacium.

(From the photo documentation of Institute of Archaeology, project Viminacium) 
before that, actually the period of Roman empire in the case of this study, they experience as a period they do not belong to and with which they are not in any relationship. This is probably the cause of the fact that illegal excavations in the whole region have mostly been carried out on ancient and prehistoric sites. As a peasant from the wider area of this Serbian region said, who also committed these illegal activities, while talking about the nuns from the nearby monastery who, according to a local story, sold the crown of the Serbian prince Lazar and got a large amount of money to renovate the monastery, "eh, that, I could never, ever, do!" (Milosavljević 2010, 58)

Although the illegal excavation of Viminacium has been stopped since the beginning of the 2000 s, permanent protection of the site was introduced, touristic development has been increasing and the local inhabitants have slowly become a part of that success, it is certain that there are a lot of people who used to commit the illegal acts in the past and still have the same desire and drive to become rich in this way. Felix Kanitz wrote that locals used to offer him coins, small bronze figurines, bracelets, needles and different dishes, but for such high prices that he could afford to buy only a few pieces. (Каниц 1989, 178) As long as there is a market for antiquities, members of local communities all around the world will try to increase their income by robbing unprotected areas, especially if they do not have any other possibility of ways of earning money and are not educated about the importance of cultural heritage protection. (Qin 2004, 298) "I do not have a job, and you can earn a lot doing this. The state is failing anyway, so who cares about those old trinkets. There are people who pay very well for this, and my children have to eat" (Tasić, Dukić, 2005b). This is just one of the statements given by locals of the villages near Viminacium in previous decades, and proves the thesis.

A great number of arable land plots in nearby villages are bought by the state for the purpose of coal exploitation, but also for the excavation and presentation of Viminacium. Nevertheless, the former owners are allowed to work the land and collect the produce until the archaeological excavations start. However, then a specific characteristic of this peasant is manifested. He thinks that the land he inherited and once worked is his forever, despite the fact that he sold it. Also, it is very often that in those fields forming the protected area of Viminacium, but still owned by the peasants, they plant those crops that are forbidden in the protected area, and whose deep roots destroy the historical layers, because it makes the land that will soon be bought more expensive. Sometimes, this leads to arguments in which it is necessary to involve the local judiciary. This can be connected to the fact that, in most Serbian villages, the state and its representatives, in this case the archaeologists, are perceived as the enemy. Also, among Serbian people, there is a widespread belief that the property that the state owns actually belongs to those who the state "seized it from" and the peasant often recognises himself as such. Damaging the state in all areas in periods of crisis is not seen as a special delict, because "the state seizes" by means of taxes and other obligatory provisions. (Milosavljević 2010, 80-82) Felix Kanitz noted this peasant feature when he wrote about a young priest in a village near Viminacium who was trying to assure him that the trade of antiquities had completely stopped and that he owned only a bag of worthless money, protesting that his village was destroyed and could not build its own church because of the low grain prices and increased taxes. (Каниц 1989, 181)

However, there is no initiative strong enough to ensure the cultural heritage of the area is preserved, even by the state. During the summer of 2011, the IX Summit of Heads of State of South East Europe was held in Viminacium. (UNESCO 2012) All the built structures visible from the approach roads were renovated, the infrastructure was repaired, illegal dumps were cleaned, and the Viminacium Archaeological Park was prepared for the meeting. The old earth road that was rarely used as a connection between the town of Kosto- 
lac and the thermo power plant in the village was paved. The visitors to the summit did not use the road passing through the old mining colony, for many years inhabited by Roma people, which was, until that point, the only proper traffic route between the aforementioned places. They did not see the poor state of the important historic buildings and the living conditions of the Roma people. (Акциони план 2015, 46) The newly paved road was a good decision and made the everyday life of the workers easier, and could have been the catalyst for making a small tourist attraction of the industrial heritage of the old mining colony. With the resettlement of the Roma people, giving them some other place with better living conditions, and the reconstruction of the old buildings that represent the industrial heritage, the tourist development of this small zone would also be possible, owing to the fact that the old road is not used by workers anymore. Will it fall into ruin and be forgotten completely?

\section{BEAUTIFYING THE COMMUNITY WITH HERITAGE}

A population develops and changes its features under the direct or indirect influence of social development. It does not receive those influences passively, but consciously changes and transforms them into features and behaviour. (Devedžić 2007, 65) The result of social influence on demographic development depends on the way the population reacts to a certain situation, and the type of reaction depends on the structure and the features of the population. Norms dictated from outside and imposed by the global society are differently accepted by certain communities, especially in villages, and these differences are an expression of the cultural specificities of a millieu. (Milosavljević 2010, 11)

An important factor in the process of the participation of the local community in developing a cultural or historical place, that can be at odds with giving the space the universal value that is necessary for tourism, is the attitude of the community towards visitors, specifically those who visit from other communities and other areas. A common phenomenon called the "demonstration effect" (Ryan 2000, 140) happens when local people, by observing tourists, start to imitate their forms of behaviour. Factors that determine the intensity of these processes are numerous and include the strength of the local culture, its flexibility and possibility of receiving new influences, the homogeneity of the culture and its acceptance by all the community members, the gap between the cultures of the host and the guest, the circumstances of their mutual contact, the type of social connection that is made from the contact, the mutual relationship of the economical powers, the motivation of both sides, but also the level of reception of other influences by the local community (Ryan 2000, 140-141). This effect has a positive influence when an area, with the adoption of other ways of behaviour, advances by making more qualitative conditions of life. However, much more often its influence is negative, when the differences in behaviour, social and financial status and the way of life of the tourists and locals are expressed too much, leading to intolerance between those two groups of actors, but also between the members of the local community, between those who adopt the novelties and those who offend that. (Ryan 2000, 140-141)

A possible future demonstration effect that will have either a positive or negative influence on local people in the villages near Viminacium may occur as a result of the influence of foreign tourists, especially on the female population and young inhabitants. Women from western countries are mostly economically independent, and their behaviour can influence the expectations of young village girls, of which many of those aged fifteen or over have not even completed primary school. (Одлука 2012, 13) The demonstration effect had a very positive impact in these villages more than a century ago. Serbian miners in Kostolac lacked expertise and 
experience and a lot of them were illiterate. Along with the fast development of the mine, which even participated in the World Fair in Paris in 1900, presented in the pavilion of the Kingdom of Serbia, interest in working in the mine started to grow. Besides the local people in the mine, experienced miners from Europe started to come, first among whom were newcomers from today's Czech Republic. Soon, the influence of these new miners was visible. It changed the way people considered their houses, their clothing and how they organised their free time, filled with music. (Вучетић 2010, 38-39) In the village, until then, peasants only knew about the accordion, Gipsy bass and violin, but the new miners introduced them to tamburitzas. (Вучетић 2010, 46) The initial distance and distrust of the poor Serbian farmers, who suddenly become miners, towards the newcomers, slowly disappeared; friendships were made and even family ties. All the newcomers brought their habits and customs with them, which slowly merged with the local ones. (Вучетић 2010, 46) This mining colony that was made from many nations disappeared, after the foundation of town of Kostolac, because most of the miners moved away to the town, which is today settled by a minimum of eighteen different ethnic groups. (Републички завод за статистику 2012, 70-71)

For a place to develop successfully, it is necessary that its inhabitants have a sense of place which consists of identity, a belief that the connection between themselves and the place exist; commitment, representing an emotional connection with the place; and dependence, that is the strength of association of personal behaviour with the place. (Jorgansen, Stedman 2001, 244) It can be differently described as a connection of emotions (excitement and feeling), cognition (opinion, knowledge and belief) and practice (action and behaviour). (Low, Artman 1992, 4-5) This sense of place as a synthesis of identity, commitment and dependence is hard to perceive in the villages of the area today, due to the great changes in the structure of the economy and the use of the physical space.
When we consider all the previously analysed relationships between the local inhabitants and other actors, it seems that the sense of place is here, limited only to dependence, and that identity and commitment have been lost over time, actually withdrawn as a result of different social processes. However, the return of a sense of place as a mentioned set that would influence the preservation of the cultural heritage and the environment itself can be justified. This is evidenced by the fact that a great number of peasants in the villages of the surrounding area that went through a similar social and economical processes through history as the Viminacium area, and that own equally valuable cultural treasures, emphasised in a scientific survey that "they are proud on the treasures their region has", but also that they regretted that state did not deal with this more seriously, giving more money for research and for securing the sites. (Milosavljević 2010, 68-70) According to them "it is a sin to take a cultural treasure, because it is from the people, and has to belong to the people, and that is the reason museums exist". (Milosavljević 2010, 68) When talking about incidental findings, most peasants regard them with approval and consider them a sort of award for those who find them. But, in case of illegal excavations, most of them think that offenders will get the punishment they deserve, "whether legal, or supreme". (Milosavljević 2010, 67) It is interesting that even the offenders that are not afraid of the law and the state punishment are afraid of God. One of them said that he did not "work" on Sundays and religious holidays because he was afraid of God's punishment. Another talked about his love of archaeology and history, which dated back to school days, and told that he collected the artefacts with love, and sold when he was in a difficult economical situation, but that later he had taken up the trade of cultural property as an occupation. (Milosavljević 2010, 55-58) One peasant from a village near Viminacium said that mostly young people committed the illegal activities, because the older generations knew it was 
damnation to rob the graves, citing examples of people who had found gold and had subsequently become immobile or sick. (Mikić 2003)

Considering the fact that "our social interaction in a large part consists of telling others what is the correct opinion, putting the guilt on the wrong opinion", and that it is "the way we build institutions, knead ideas of the others and the way the others knead our ideas, until they get a common form" (Milosavljević 2010, 82-83), maybe the influence of those who "are proud of the treasures their region has" and those who think "it is a sin to take a cultural treasure", or the others who do not "work" on Sundays, can make the sense of a place being whole, return the emotions to all the inhabitants, deepen the cognition and direct the practice towards the preservation of the place. After restoring the holistic sense of a place, local inhabitants in the Viminacium area will not name the biggest Roman bricks "Kostolac bricks", and then sell them at the local market. This can be connected to the fact that a cultural and historic place can be developed by a community only if, along with the inherited cultural and acquired economical capital, it owns the social capital. For a description of the capability of the association of local people with the aim of preserving its history, culture and spirituality, another story serves well. In the building of a local church at the beginning of the $19^{\text {th }}$ century, all the inhabitants helped, while the archaeologist and researcher of Viminacium, Miloje Vasić, worked on a design for the building. Bells with the names "faith", "love" and "hope" were gifted to the church by the authority of the mine. Next to the church, a mausoleum was built, where Serbian soldiers, who had died in a battle at this place, during the First World War, were buried. (Спасић 1995) (Fig 4)

Guilt for the lack of interest of the local people in cultural heritage partly lies in the relationship of most researchers towards this topic that has prevailed in recent decades. During archaeological research it is necessary to collaborate with the local community, not only employ them as workers. They have to be involved in forming the development goals of the area, as well as participate in public discussions. (Merriman 2004, 14) Viminacium Archaeological Park has started to develop this method of collaboration, but it is always necessary to work more on deepening the relationship. One of the biggest benefits archaeology can bring to local communities is the spread of experience and ideas. It can be one of the ways of removing cultural barriers between people, and developing their mutual connection with a common interest in the research of the past. The vision of culture held by archaeologists and the local community is different. Joint work can change that; it can form a common vision of a culture and the method of its maintenance and preservation. (Parker Pearson, Ramilisonina 2004, 236-237) Besides that, by volunteering, self confidence is built, and equality and rapprochement are promoted. (Palmer 2008, 9-10) A positive example of the relationship between professional archaeologists and the local community can be found in England, but that requires strong police control and a lawfully regulated state. There, in archaeological excavations of green-field locations, professional archaeologists work with local people, especially those that use metal detectors as a hobby. The volunteer work of metal detectorists and the work of other local people in the scope of measuring, geophysical research, excavation, cleaning and conservation of finds is being done under the control and with the advice of professional archaeologists. The use of metal detectors in England is not forbidden, but it is limited to places not protected by law, with no archaeological excavations going on, and for which there is the permission of the land owner. These detectorists are required to report gold and silver artefacts, as well as all prehistoric finds, together with all other artefacts they find next to them. The authorities know for sure that there will be those who will not report their finds, but that their criminal activity will be revealed in the course of the other illegal activities, and then they will be prosecuted. A large number of finds 

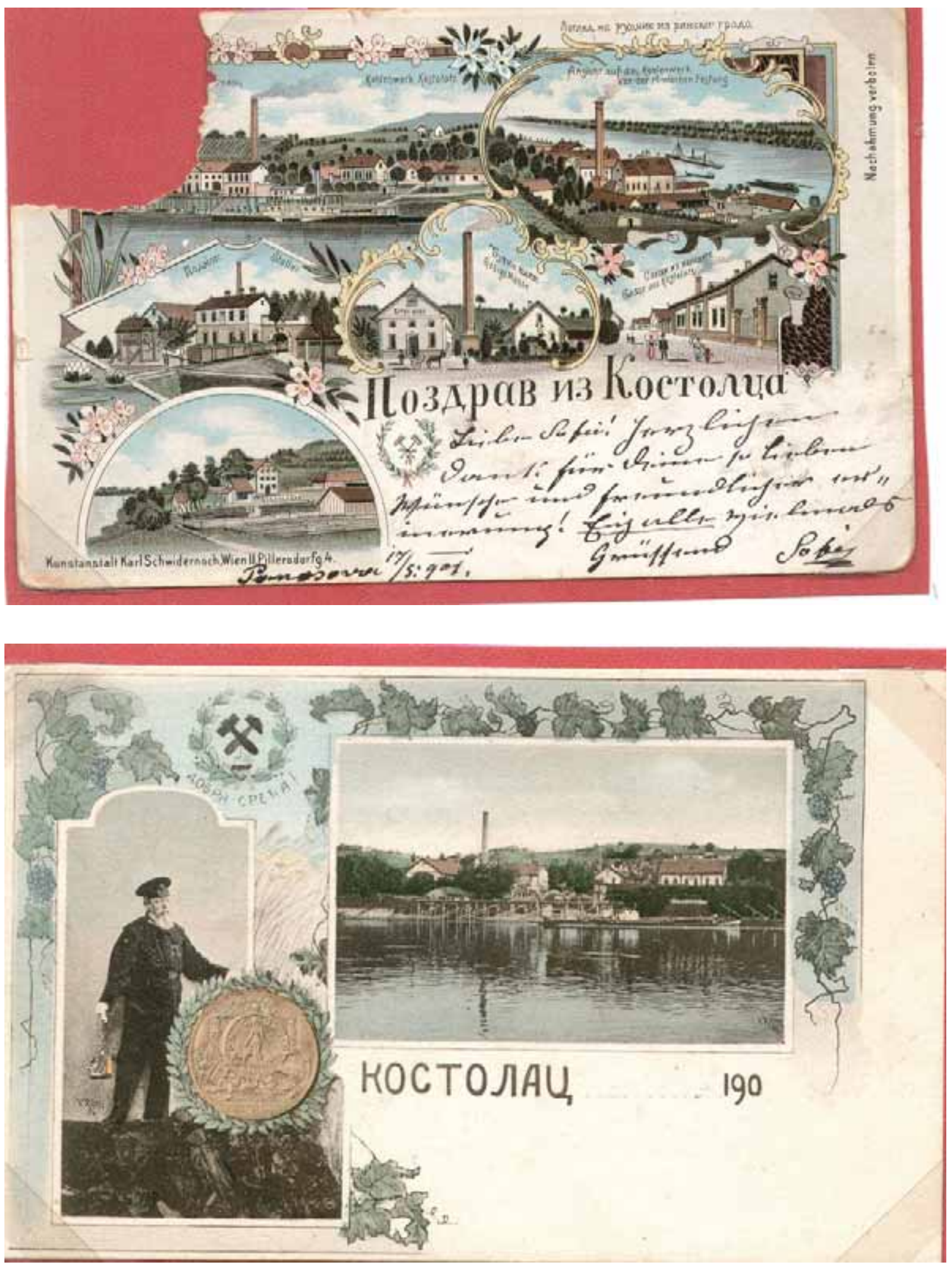

Fig. 4 Connection between the community and Viminacium is visible even on old postcards. Upper figure: a postcard showing the old town of Kostolac, with one of the paintings named "a view to the mine from the Roman city". Figure below: mining symbols are shown together with Viminacium coat of arms in a golden emblem; today, emblem of the new town of Kostolac also contains the representation of Viminacium. (From: "Istorija", Ogranak TE-KO Kostolac. O nama, http://www.te-ko.rs/o-nama/istorija; accessed September, 26th 2016). 
uncovered by metal detectors originate from already cultivated land, with disturbed chronological layers, so in this way they help to prevent the destruction of artefacts, something which is inevitable in agricultural work. Following the volunteer research, the archaeologists organise exhibitions, meetings and discussions, where the local community can learn the methods of archaeology and about their cultural heritage. Additionally, the detectorists are shown ways of preserving layers during the excavations and the importance of reporting finds to the authorities. (Macnab 2004, 272-291) Mihailo Valtrović, more than a century ago, did something similar during the first official excavations of Viminacium. He let peasants take bricks and stones from the graves he had already researched. "My disapproval would not keep the Kostolac people from excavating those graves, which I would, after surveying and describing, bury again. With my approval, I gained their trust, so they used to bring me the finds they had already found before, told me where there were more of them and who owned them, and called me to dig on their fields too, assuring me that there would be an abundance of graves and antiquities. " (Валтровић 1884b, 52)

\section{CONCLUSION}

Socio-economical development under the influence of tourism is very specific, because of the great number of changes that happen, but also because of "the planetary dimensions" of tourism. (Devedžić 2007, 65) Tourism develops complementary activities, increases employment, has an influence on the bigger engagement of women, and causes the transition from primary to tertiary activities. (Devedžić 2007, 70) Sustainable tourist development is that which can make the quality of life of the local communities better, gives the visitors a superior experience, preserves the quality of the environment and culture of the local community, but also creates a balance between the host, the guest and the environment. (Moscardo 2003, 3-4) This is the way the Kostolac area can survive after the end of its mining industry. The aforementioned large economical capital of the peasants that work abroad can be preserved by investing money in tourist development of the area. This can be the reason for young people to stay in their birth place, be educated in fields other than mining and energy, and become capable of leading future development. It is necessary to increase information about cultural heritage, to raise awareness about the importance of cultural heritage, to encourage local people to actively participate in the process of decision making about its development (Одлука 2012, 81, 152), always keeping in mind that the development has to be planned on the basis of every specific village, its tradition, culture, customs and people. (Dragićević-Šešić 1991, 45) In that way they will take responsibility for future processes in the area. (Palmer 2008, 9-10)

As part of the rich antique heritage of the Republic of Serbia and as the initiator of future plans to connect the Roman sites in the national and international cultural and tourist route, Itinerarium Romanum Serbiae, (Korać et al. 2009, Maksin et al. 2011, 316-327) Viminacium inspires an awareness of cherishing the heritage, reminds us of the international importance of local cultural heritage, and demonstrates the possibility of sustainable development and the prosperity of local communities through archaeological tourism. (Одлука 2009) In such a way, peasants can earn from their land whilst still preserving its rich cultural and historical heritage. The appropriation of a historic place does not mean the illegal usurpation of cultural properties; instead it can represent care for the place, a feeling of joy when it progresses and sorrow when it falls. The value of an area can not be found only in its physical elements, it is a place where the process of building the identity of a region is initiated. (Röhring 2011, 1)

It is said that geo-tourism "can help to beautify ugly places and enrich poor places." (Tourtellot 2009, 6) In a North Carolina town, in the USA, 
"a group of volunteers got together to beautify ... and protect the environment" as "an effort to raise awareness and show residents how easy it can be to take care of the environment". (Beairshelle 2016) The Georgetown Heritage Society in Georgetown, Texas, was formed "to assist in the preservation of buildings... historical sites, works of art... records and writings... to perpetuate those customs ... and traditions and folklore which seem to beautify and enrich the community life." (The Georgetown Heritage Society) The Historical Society of Marine City in Michigan, USA "is sponsoring an event to raise funds to help beautify local neighbourhoods" because "when you see an older home with some of the gingerbread trim, it gives you pride in your city." (Packer 2016) An organisation from the USA, named Beautify Earth, "creates public and private art projects...for the purpose of instilling community pride in impoverished or neglected communities". (Beautify Earth)

So, the verb to beautify does not only refer to aesthetics or technical development. In the case of Viminacium, and the surrounding rural area, it is obvious that culture and tourism have to take a role in the education of the local community as a way of beautifying it, making it able to further beautify their living space. To beautify does mean to give beauty - to make nice houses, green lawns and clean streets in the area, but what is equally important, to create a community that is built on the pride, strength and power originating from its cultural and historical heritage.

\section{BIBLIOGRAPHY}

\section{Beairshelle, E. 2016}

Conservation group, volunteers team up to beautify Raleigh greenway trail.

CBCS North Carolina WNCN.com 09.04.2016.

http://wncn.com/2016/04/09/conserva-

tion-group-volunteers-team-up-to-beautify-ra-

leigh-greenway-trail/

(accessed $5^{\text {th }}$ May 2016).

\section{Beautify Earth.}

The Story. Mission.

http://beautifyearth.org/the-story/

(accessed $5^{\text {th }}$ May 2016).

\section{Devedžić, M. 2007}

"Prilog izučavanju uticaja turizma na demografski razvitak". Stanovništvo (Beograd) XLV, br. 2/07 (2007) str. 63-81.

\section{Dragićević-Šešić, Milena D. 1991}

"Očuvanje kulturnog identiteta i kolektivnog sećanja sela kao uslov integralnog razvoja". Zbornik Matice srpske za društvene nauke (Novi Sad): 45-57.

\section{Ela Palmer Heritage 2008}

The Social Impacts of Heritage-led Regeneration. London: Ela Palmer Heritage.

\section{Годишњи извештај 2014}

Електропривреда Србије. Београд: ЈП Електропривреда Србије.

\section{Jain, P. 2008}

"Preserving Cultural Landscapes - A Cross-Cultural Analysis". In: Exploring the Boundaries of Historic Landscape Preservation: Proceedings of the Twenty-ninth Annual Meeting of the Alliance for Historic Landscape Preservation 2007 Athens, Georgia. Eds. Cari Goetcheus, Eric MacDonald, pp.15-29, Clemson, SC: Clemson University Digital Press, 2008. http://www.clemson.edu/cedp/ 
press/pubs/alliance/02_jain.pdf

(accessed $5^{\text {th }}$ May 2016).

Jorgensen, B.S., Stedman, R.C. 2001

"Sense of Place as an Attitude: Lakeshore Owners Attitudes Toward Their Properties". Journal of Environmental Psychology (Amsterdam), 21 (2001: 233-248).

\section{Канцеларија за ЛЕР 2015}

Акциони план за унапређење положаја Рома на територији Града Пожаревца за период 20162020 године. Пожаревац: Канцеларија за ЛЕР.

\section{Каниц, Ф. 1989}

Србија: Земља и становничтво од римског доба до краја XIX века, Прва књига. Београд: Српска књижевна задруга.

\section{Korać, M., Golubović, S., Mrđić, N. 2009}

Itinerarium Romanum Serbiae/Putevima rimskih imperatora, Centre for New Technology Viminacium, Belgrade.

\section{Локални план управљања отпадом 2009}

Пожаревац: Град Пожаревац.

\section{Low, S.M., Artman, I. 1992}

"Place attachment: A conceptual inquiry". In: Place attachment. Eds. Irvin Altman, Setha M. Low. New York: Plenum Press, 1992: 1-12.

\section{Lukić, Ž. 2009}

"Gde su zlatne kočije". Danas, Braničevo online, 19.11.2009. http://www.danas.rs/dodaci/branicevo/gde_su_ zlatne_kocije.59.html?news_id=177181 (accessed $5^{\text {th }}$ May 2016).

\section{M.V.2012}

"U njima danas uglavnom žive samo starci", OKRUG 189/IV 2012, https://issuu.com/bokanboss/docs/okrug_ broj_189 (accessed $5^{\text {th }}$ May 2016).

\section{Macnab. N. 2005}

Archaeology and metal-detecting: A model for engaging the local community in a greenfield development. York: The Joseph Rowntree Foundation.

\section{Maksin, Marija, et al. 2011}

Održivi razvoj turizma u Evropskoj uniji i Srbiji. Beograd: Institut za arhitekturu i urbanizam Srbije.

\section{Mašinski fakultet Univerziteta u Beogradu 2010}

TE Kostolac B, postrojenje za odsumporavanje dimnih gasova: Studija o proceni uticaja na životnu sredinu. Beograd: JP Elektroprivreda Srbije.

\section{Merriman, N. 2004}

"Introduction: diversity and dissonance in public archaeology". In: Public Archaeology. Ed. Nick Merriman. London \& NewYork: Routledge, 2004: 1-17.

\section{Mikić, V. 2003}

“'Divlji arheolozi”. НИН Online 2727, 2003, http://www.nin.co.rs/2003-04/03/28156.html (accessed $5^{\text {th }}$ May 2016).

\section{Milosavljević, Lj. 2010}

Baština i kriminal: Seljak kao nadri-arheolog. Etnoantropološki problemi. eMonografije. Knjiga prva. Beograd: Univerzitet u Beogradu - Filozofski fakultet, Odeljenje za etnologiju i antropologiju, 2010.

http://www.anthroserbia.org/Content/PDF/Publications/62221e5bec3e43f7814671cd0d18d6e1. pdf

(accessed $5^{\text {th }}$ May 2016).

\section{Mirković, M. 1968}

Rimski gradovi na Dunavu u Gornjoj Meziji. Beograd: Arheološko društvo Jugoslavije. 


\section{Mitchell, N., Buggey, S. 2000}

"Protected Landscapes and Cultural Landscapes: Taking Advantage of Diverse Approaches". The George Wright Forum (Hancock, MI), Vol. 17, No.1 (2000): 35-46.

\section{Moscardo, G. 2003}

"Interpretation and Sustainable Tourism: Functions, examples and principles. The Journal of Tourism Studies (Townsville), Vol. 14, No.1 (2003): 2-13

\section{Република Србија - Републички завод за} статистику 2014

Попис становништва, домаћинстава и станова 2011. у Републици Србији. Становништво: делатност, подаци по општинама и градовима. Београд: Републички завод за статистику.

\section{Република Србија - Републички завод за статистику 2013}

Попис становништва, домаћинстава и станова 2011. у Републици Србији. Становништво: школска спрема, писменост и компјутерска писменост, подаци по општинама и градовима. Београд: Републички завод за статистику.

\section{Република Србија - Републички завод за статистику 2012}

Попис становништва, домаћинстава и станова 2011. у Републици Србији. Становништво: национална припадност, подаци по општинама и градовима. Београд: Републички завод за статистику.

\section{Решење 1949}

"Решење Завода за заштиту и научно проучавање споменика културе НРС" бр. $428 / 49$.

\section{Rodwell, D. 2007}

Conservation and Sustainability in Historic Cities. Oxford,UK: Blackwell Publishing Ltd.

\section{Одлука 1979}

“Одлука о утврђивању непокретних културних добара од изузетног значаја и од великог значаја", Службени гласник СРС, 14/79, 30/89.

\section{Одлука 2009}

“Одлука оутврђивању локалитета Виминациум у атару села Стари Костолац за археолошко налазиште”, Службени гласник РС, 102.

\section{Одлука 2012}

“Одлука о доношењу Просторног плана Града Пожаревца", Службени гласник Града Пожаревиа, 10.

\section{Packer, J. 2016}

Historical Society of Marine City aims to beautify historic homes, businesses. The Voice. 17.03.2016.

http://www.voicenews.com/articles/2016/03/17/ life/doc56e1d202c4116481339574.txt (accessed $5^{\text {th }}$ May 2016)

\section{Parker Pearson, M., Ramilisonina. 2004}

"Public Archaeology and Indigenous Communities". In: Public Archaeology. Ed. Nick Merriman. London \& NewYork: Routledge, 2004: 224-239.

\section{Qin, D. 2004}

"The Effects of the Antiquities Market on Archaeological Development in China“. In: Public Archaeology. Ed. Nick Merriman. London \& NewYork: Routledge, 2004: 292-299.

\section{Републичка агенција за просторно планирање 2009}

Стратегија одрживог развоја града Пожаревиа 2009-2013 године. Пожаревац: Град Пожаревац.

\section{Röhring, A. 2011}

"Cultural landscape as action arena - an identity-based concept of region-building". Regional Studies Association Annual International Confer- 
ence 2011, Newcastle University, Newcastle-upon-Tyne, UK, 17th - 20th April 2011, http://www.regionalstudies.org/uploads/funding/ conferences/presentations/international-conference-2011/rohring.pdf

(accessed $5^{\text {th }}$ May 2016).

\section{Ryan, C. 2000}

"Demonstration Effect". In: Jafar Jafari. Encyclopaedia of Tourism. London \& NewYork: Routledge, 2000: 140-141.

\section{Спасић, Д. 1995}

“Црква св. великомученика Георгија у Костолцу”, Саборност (Пожаревац) 2/I (1995). http://casopis.sabornost.org/tekst.php?d=3\&serija $=1 \&$ id_sveska $=2 \& i d$ tekst $=13$

(accessed $5^{\text {th }}$ May 2016).

\section{Спасић-Ђурић, Д. 2009}

“Културно-историјска вертикала Костолца”. У: Републичка агенција за просторно планирање. Стратегија одрживог развоја града Пожаревиа 2009-2013 године. Пожаревац: Град Пожаревац, 2009: 15-17.

\section{Шпехар, П. 2007}

“Средњовековни налази из области Браничева”. Гласник Српског археолошког друштва (Београд), 23 : 363-390.

\section{Tasić, S., Dukić, S. 2005a}

"Ukor umesto presude". Večernje novosti online. 16.12.2005.

http://www.novosti.rs/dodatni_sadrzaj/clanci.119.html:277469-Укор-уместо-пресуде (accessed $5^{\text {th }}$ May 2016).

\section{Tasić, S., Dukić, S. 2005b}

"Bogatstvo u - ćupu".. Večernje novosti online. 14.12.2005.

http://www.novosti.rs/dodatni_sadrzaj/clanci.119.html:277467-Bogatstvo-u---cupu (accessed $5^{\text {th }}$ May 2016).

\section{The Georgetown Heritage Society}

A History Lesson.

http://georgetownheritagesociety.org/about/ georgetown-heritage-society/

(accessed $5^{\text {th }}$ May 2016).

\section{Tourtellot, J. B. 2009}

About Geotourism. In USAID Conservation of Central American Watersheds Program. Deliverable No.3: Formalized Sustainable Tourism Cluster In Bocas Del Toro, Panama, (ed.) USAID central America, 6-7.

\section{UNESCO 2012}

Dialogue among Civilizations: Summit of the

Heads of State of South-East Europe - Contemporary Art and Reconciliation in South-East Europe, Republic of Serbia, 1-2 September 2011. Ed. Ann-Belinda Preis., Maria Linda Tinio - Le Douarin. UNESCO 2012.

http://unesdoc.unesco.org/images/0021/002164/216440E.pdf

(accessed $5^{\text {th }}$ May 2016).

\section{Валтровић, М. 1884a}

“Откопавања у Костолцу”. Старинар (Београд), 1, 1. део (1884: 3-14.

\section{Валтровић, М. 1884b}

“Откопавања у Костолцу”. Старинар (Београд), 1, 2. део (1884), стр.49-63

\section{Вучетић, М. 2010}

Из историје српских угљенокопа: Јаме костолачког мајдана. Београд: ЈП “Електропривреда Србије”. 
REZIME

ARHEOLOŠKI PARK

VIMINACIJUM: KULTURNO

NASLEĐE I LEPOTA ZAJEDNICE

\section{KLJUČNE REČI: VIMINACIJUM, LOKALNA \\ ZAJEDNICA, KULTURNO NASLEĐE, MESTO, IDENTITET, ODANOST, ZAVISNOST, ZNANJE, ULEPŠATI, ZANEMARITI, TURIZAM.}

Za proučavanje odnosa lokalne zajednice prema kulturnom nasleđu u procesu napretka jedne teritorije izabrano je arheološko nalazište Viminacijum, koje svoj dosadašnji razvoj malo duguje samoj zajednici. Naprotiv. Sve do početka XXI veka, uvođenja stalne zaštite lokaliteta i oživljavanja mesta pristizanjem turista, prekopavanje antičkog Viminacijuma je bila svakodnevica meštana okolnih sela. Ako lepotom nazovemo sve pozitivne osobine jedne zajednice koje čine da u očima posetilaca ona izgleda kao domaćin koji čuva i brine o svojoj okolini i kulturnom nasleđu, onda lepota lokalne zajednice okoline Viminacijuma već dugo u velikoj meri zavisi od razvoja samog arheološkog nalazišta. Danas je arheološko nalazište Viminacijum savremeni arheološki park čiji je razvoj doneo uređenje prostora i komunikacija na široj teritoriji i u kome je zaposleno lokalno stanovništvo.

Razvoj jednog prostora se uvek mora planirati na osnovu tradicije i običaja ljudi koji u njemu žive i oni moraju aktivno biti uključeni u proces odlučivanja, Međutim, navike jedne zajednice, njena svest o sebi i njen odnos prema okruženju i nasleđu su najveća prepreka ne samo u turističkom razvoju predela, već i u razumevanju potrebe za ovakvim razvojem. Zajednica mora verovati u vezu između sebe i mesta na kome živi, biti ponosna na nju i ta veza se mora stalno nadgrađivati, delovanjem na njihova osećanja, znanja i ponašanja. Zato je neophodno shvatiti da je socijalni razvoj i edukacija zajednice u oblasti očuvanja i prezentacije kulturnog nasleđa jedna od najvažnijih obaveza onih koji upravljaju jednom oblasti.
Priroda i obradivo zemljište na prostoru oko arheološkog nalazišta Viminacijum polako kroz decenije postaju industrijsko okruženje i vekovna ljudska delatnost poljoprivrede polako zamire. Nakon završetka industrijskih aktivnosti, turizam može biti jedna od najvažnijih privrednih grana koja će pomoći u razvoju ove teritorije. 